\title{
Suitability of SBR for Wastewater Treatment and Reuse: Pilot-Scale Reactor Operated in Different Anoxic Conditions
}

\author{
Omar Alagha ${ }^{1, *(\mathbb{D}}$, Ahmed Allazem ${ }^{2}$, Alaadin A. Bukhari ${ }^{3}$, Ismail Anil ${ }^{1}(\mathbb{D}$ and \\ Nuhu Dalhat Mu'azu ${ }^{1}$ (D) \\ 1 Environmental Engineering Department, College of Engineering A13, Imam Abdulrahman Bin Faisal \\ University, Main Campus, Dammam 31451, Saudi Arabia; ianil@iau.edu.sa (I.A.); \\ nmdalhat@iau.edu.sa (N.D.M.) \\ 2 Civil and Environmental Engineering Department, College of Engineering, King Fahad University of \\ Petroleum and Minerals, Dhahran 31261, Saudi Arabia; ahmedallazem@gmail.com \\ 3 The Electricity \& Co-Generation Regulatory Authority, Riyadh 12711, Saudi Arabia; abukhari@kfupm.edu.sa \\ * Correspondence: oaga@iau.edu.sa; Tel.: +966-506-61-6532
}

Received: 3 February 2020; Accepted: 26 February 2020; Published: 2 March 2020

\begin{abstract}
The present study investigates the performance of a pilot-scale Sequencing Batch Reactor (SBR) process for the treatment of wastewater quality parameters, including turbidity, total suspended solids (TSS), total solids (TS), nitrogen (ammonia $\left(\mathrm{NH}_{3}-\mathrm{N}\right)$, nitrite $\left(\mathrm{NO}_{2}{ }^{-}\right)$, and nitrate $\left(\mathrm{NO}_{3}{ }^{-}\right)$, phosphate $\left(\mathrm{PO}_{4}{ }^{3-}\right)$, the chemical oxygen demand (COD), and the 5-day biological oxygen demand $\left(\mathrm{BOD}_{5}\right)$, from municipal wastewater. Two scenarios, namely, pre-anoxic denitrification and post-anoxic denitrification, were investigated to examine the performance of a pilot-scale SBR on the wastewater quality parameters, particularly the nitrogen removal. The correlation statistic was applied to explain the effects of operational parameters on the performance of the SBR system. The results revealed that the post-anoxic denitrification scenario was more efficient for higher qualify effluent than the first scenario. The effluent concentrations of the targeted wastewater quality parameters obtained for the proposed SBR system were below those of the local standards, while its performance was better than that of the North Sewage Treatment Plant, Dharan, Eastern province, Kingdom of Saudi Arabia (KSA), in terms of the $\mathrm{BOD}_{5}, \mathrm{COD}, \mathrm{TN}$, and $\mathrm{PO}_{4}{ }^{3-}$ treatment efficiencies. These results indicated the suitability of SBR technology for wastewater treatment in remote areas in the KSA, with a high potential of reusability for sustainable wastewater management.
\end{abstract}

Keywords: sequencing batch reactor; pilot-scale treatment; nitrogen and phosphorus removal; domestic wastewater treatment; sustainable wastewater management; arid regions

\section{Introduction}

The activated sludge system (ASS) has been the conventional technique adopted by the majority of municipal wastewater treatment plants, globally, for wastewater treatment [1]. In recent years, the sequencing batch reactor (SBR), an enhanced form of the ASS process, has become a popular replacement technique due to its unique merits [2]. The SBR is one of the integrated systems for anaerobic-aerobic bioreactors in which the wastewater is treated in a fill and draw method [3]. The process of a typical SBR mainly consists of five steps, conducted in the following sequence: filling, reacting, settling, decanting, and idle [4,5]. In the first phase (the filling phase), the wastewater influent and additional enhancement substrate (if required) are added, from which up to $75 \%$ of the container reactor volume can be occupied. During the filling period, mixing with or without aeration can be practiced. During the reaction phase, which is the second step of the SBR process, considering specific 
environmental conditions, the substrate (ammonium nitrogen) is oxidized to nitrates, and the change of its form takes place in the reactor, which contains particular bacteria responsible for the substrate degradation [6]. In the third phase, the settling period involves the separation of the solids from the effluent, providing the colloidal solids and the suspended solids with enough time to accumulate and settle [7]. The decanting step is the fourth stage of the process, in which the removal of treated effluent from the treatment tank is achieved. In the last step (the idle phase), the sludge is removed from the container, and this phase is only necessary for multi-chamber systems [8-10].

The use of the SBR process is more prevalent in industrial wastewater treatment because of its compactness and the high efficiency of the chemical oxygen demand (COD), biological oxygen demand (BOD), and ammonia nitrogen removal [11-13]. However, SBR process deployment for domestic wastewater treatment is rare, since domestic wastewater usually needs large-capacity plants due to higher wastewater flow rates [14]. Conventional biological wastewater treatment plants using ASS have some disadvantages, though they can work adequately under proper installation and maintenance [15]. However, the SBR process, as an enhanced form of the conventional treatment system, presents flexibility for the treatment of variant influents, the lowest operator interaction, an alternative for aerobic and anaerobic environments in the same chamber, an excellent oxygen interaction with microorganisms and substrates, a lesser footprint, a superior removal efficiency, and the requirement of less energy input [16-18]. These benefits validate the increased interest in the adoption of the SBR process for the treatment of both municipal and industrial wastewater [19]. Nevertheless, anaerobic and aerobic cycle times in the SBR system may generate some issues regarding controlling the anaerobic-aerobic microbial groups and, therefore, selection and enhancement of the biomass become necessary [20]. Regulation of the anoxic and oxic phases during the SBR process can enrich the targeted microbial population, and hence, improve the process efficacy. The duration of the phases, dissolved oxygen concentration, and mixing conditions can be changed in accordance with the particular requirements of the treatment plants [20].

There are two main types of biological denitrification: pre-anoxic and post-anoxic processes [11,21,22]. In pre-anoxic denitrification, the anoxic phase is located upstream of the aerobic phase. The electron donor in the anoxic container is the available organic substrate. In the post-anoxic operation, the oxic phase followed by the anoxic basin is the primary process. The endogenous decay of biomass provides the source of electron donor in the anoxic tank [23]. The organic substrate in the raw wastewater consumed in the process of carbon removal and nitrification simultaneously occurs [24].

In biological nitrogen removal, the scarcity of biodegradable organic substrate to nitrogen compounds (i.e., low $\mathrm{C} / \mathrm{N}$ ratio) is considered one of the restrictive factors [25]. Along with other heterotrophs, denitrifying bacteria are known to compete for a carbon source. Only a small carbon to nitrogen ratio in the influent accelerates the carbon deficiency, producing unstable instantaneous denitrification. The average COD/TKN ratio in domestic wastewater was reported to be beneath 6 [26]. Beccari, et al. [27] validated that the biological removal of nitrogen can be appropriately accomplished with a COD/TKN ratio of 13. Fontenot, et al. [28] proved that the $\mathrm{C} / \mathrm{N}$ ratio of 10:1 provided excellent results in terms of the maximum nitrogen and carbon removal from wastewater. In 2012, Jin and Li [29] investigated the capability of a laboratory-scale SBR in the removal of nitrogen and phosphorus. Using different $\mathrm{C} / \mathrm{N}$ ratios, they found an optimum $\mathrm{C} / \mathrm{N}$ ratio (10:1) for $\mathrm{TN}$ removal. Guo, et al. [30] reported a study that investigated the effect of sludge fermentation on the nitrogen removal efficiency from low $\mathrm{C} / \mathrm{N}$ wastewater using a $9 \mathrm{~L}$ SBR. By controlling the $\mathrm{pH}$ and dissolve oxygen (DO), they found that the removal efficiency of $\mathrm{TN}$ reached up to $93.5 \%$.

As mentioned earlier, pre-anoxic denitrification consists of an anoxic zone followed by an oxic zone; in the SBR system, the pre-anoxic denitrification can be provided by increasing the filling time without any aeration (anoxic zone) and decreasing the settling time. For the post-anoxic denitrification in which the oxic zone is applied before the anoxic zone, the settling time is increased (without any aeration) and the filling time is decreased (regardless of whether the aeration step takes place or not). 
The purpose of this study was to investigate the performance of a pilot-scale SBR for the treatment of municipal wastewater by testing different anoxic conditions in the SBR reactor and comparing the effluent quality with those of conventional ASS. Therefore, the study experimentally examined the suitability of the SBR process as a decentralized wastewater treatment system for evaluating its effectiveness as an alternative system for sustainable wastewater treatment and management in remote arid areas of the Kingdom of Saudi Arabia (KSA), where conventional treatment processes are lacking.

\section{Materials and Methods}

\subsection{Characteristics of the Studied Wastewater}

The raw wastewater (influent) and treated wastewater (effluent) samples were collected on a daily basis from the North Sewage Treatment Plant (NSTP), Dhahran, KSA. The NSTP is an activated sludge wastewater treatment plant with an average flow rate of $52,000 \mathrm{~m}^{3} \mathrm{~d}^{-1}$, receiving only domestic wastewater from Dhahran and environs. The collected samples were immediately transferred to the Biological Processes Laboratory of Environmental Engineering Department, Imam Abdulrahman Bin Faisal University, and analyzed for the $\mathrm{pH}$, turbidity (turb.), total suspended solids (TSS), total solids (TS), nitrite-nitrogen $\left(\mathrm{NO}_{2}-\mathrm{N}\right)$, nitrate-nitrogen $\left(\mathrm{NO}_{3}-\mathrm{N}\right)$, ammonia-nitrogen $\left(\mathrm{NH}_{3}-\mathrm{N}\right)$, total nitrogen $(\mathrm{TN})$, phosphate $\left(\mathrm{PO}_{4}{ }^{3-}\right)$, chemical oxygen demand (COD), and 5-day biological oxygen demand $\left(\mathrm{BOD}_{5}\right)$, according to the procedures described in "The Standard Methods for the Examination of Water and Wastewater" [31]. Table 1 indicates the descriptive statistical analysis summary of the parameters measured for the influent of NSTP during the studied period.

Table 1. Statistical summary of the parameters measured for the influent of the North Sewage Treatment Plant (NSTP).

\begin{tabular}{ccccccc}
\hline \multirow{2}{*}{ Parameter * $^{*}$} & \multirow{2}{*}{ Unit } & \multicolumn{5}{c}{ Influent } \\
\cline { 3 - 7 } & & Min & Max & Mean & SD & Median \\
\hline pH & $\mathrm{pH} \mathrm{unit}$ & 7.13 & 8.06 & 7.44 & 0.239 & 7.35 \\
Turbidity & $\mathrm{NTU}$ & 34.6 & 187 & 81.3 & 37.8 & 72.2 \\
$\mathrm{TSS}$ & $\mathrm{mg} \mathrm{L}^{-1}$ & 283 & 1,737 & 887 & 375 & 792 \\
$\mathrm{TS}$ & $\mathrm{mg} \mathrm{L}^{-1}$ & 3187 & 4482 & 3810 & 365 & 3684 \\
$\mathrm{NO}_{2}-\mathrm{N}$ & $\mathrm{mg} \mathrm{L}^{-1}$ & 0.006 & 0.036 & 0.015 & 0.007 & 0.017 \\
$\mathrm{NO}_{3}-\mathrm{N}$ & $\mathrm{mg} \mathrm{L}^{-1}$ & 0.032 & 0.454 & 0.165 & 0.135 & 0.155 \\
$\mathrm{NH}_{3}-\mathrm{N}$ & $\mathrm{mg} \mathrm{L}^{-1}$ & 5.47 & 27.2 & 14.6 & 4.83 & 14.2 \\
$\mathrm{TN}$ & $\mathrm{mg} \mathrm{L}^{-1}$ & 9.36 & 20.8 & 17.2 & 3.91 & 16.9 \\
$\mathrm{PO}_{4}{ }^{3-}$ & $\mathrm{mg} \mathrm{L}^{-1}$ & 0.295 & 4.54 & 2.23 & 1.26 & 2.24 \\
$\mathrm{COD}$ & $\mathrm{mg} \mathrm{L}^{-1}$ & 68.0 & 359 & 180 & 70.9 & 179 \\
$\mathrm{BOD}_{5}$ & $\mathrm{mg} \mathrm{L}^{-1}$ & 48.0 & 144 & 79.9 & 25.8 & 72.0 \\
\hline
\end{tabular}

* Total suspended solids (TSS), total solids (TS), nitrite-nitrogen $\left(\mathrm{NO}_{2}{ }^{-} \mathrm{N}\right)$, nitrate-nitrogen $\left(\mathrm{NO}_{3}{ }^{-} \mathrm{N}\right)$, ammonia-nitrogen $\left(\mathrm{NH}_{3}-\mathrm{N}\right)$, total nitrogen $(\mathrm{TN})$, phosphate $\left(\mathrm{PO}_{4}{ }^{3-}\right)$, chemical oxygen demand (COD), and 5-day biological oxygen demand $\left(\mathrm{BOD}_{5}\right)$.

\subsection{Pilot-Scale SBR System Description}

In this study, pre-denitrification and post-denitrification processes were investigated in the SBR process to find the most appropriate method for the removal of pollutants. Figure 1 shows a schematic diagram of the pilot-scale SBR system used in the present work. The system consists of a feed tank with a capacity of $700 \mathrm{~L}$ and a cylindrical oxidation reactor with a capacity of $300 \mathrm{~L}$, which were made from inert, transparent methacrylate material. The oxidation reactor includes a stainless-steel agitator and air diffuser. The system comprised (1) feeding, decanting, and waste-sludge pumps with a maximum flow-rate of $60 \mathrm{~L} \mathrm{~h}^{-1}$; (2) a diaphragm compressor with a stainless-steel body and flow rate of $1.2 \mathrm{Nm}^{3}$ $\mathrm{h}^{-1}$; and (3) a flowmeter for measuring the feed flow rate of air to the reactor with a range of $0-1500 \mathrm{NL}$ $\mathrm{h}^{-1}$. The pilot-SBR reactor system has a board-type microprocessor-controlled $\mathrm{pH}$-meter, temperature sensor, and DO-meter with a detection range between 0 and $10 \mathrm{ppm}$. 


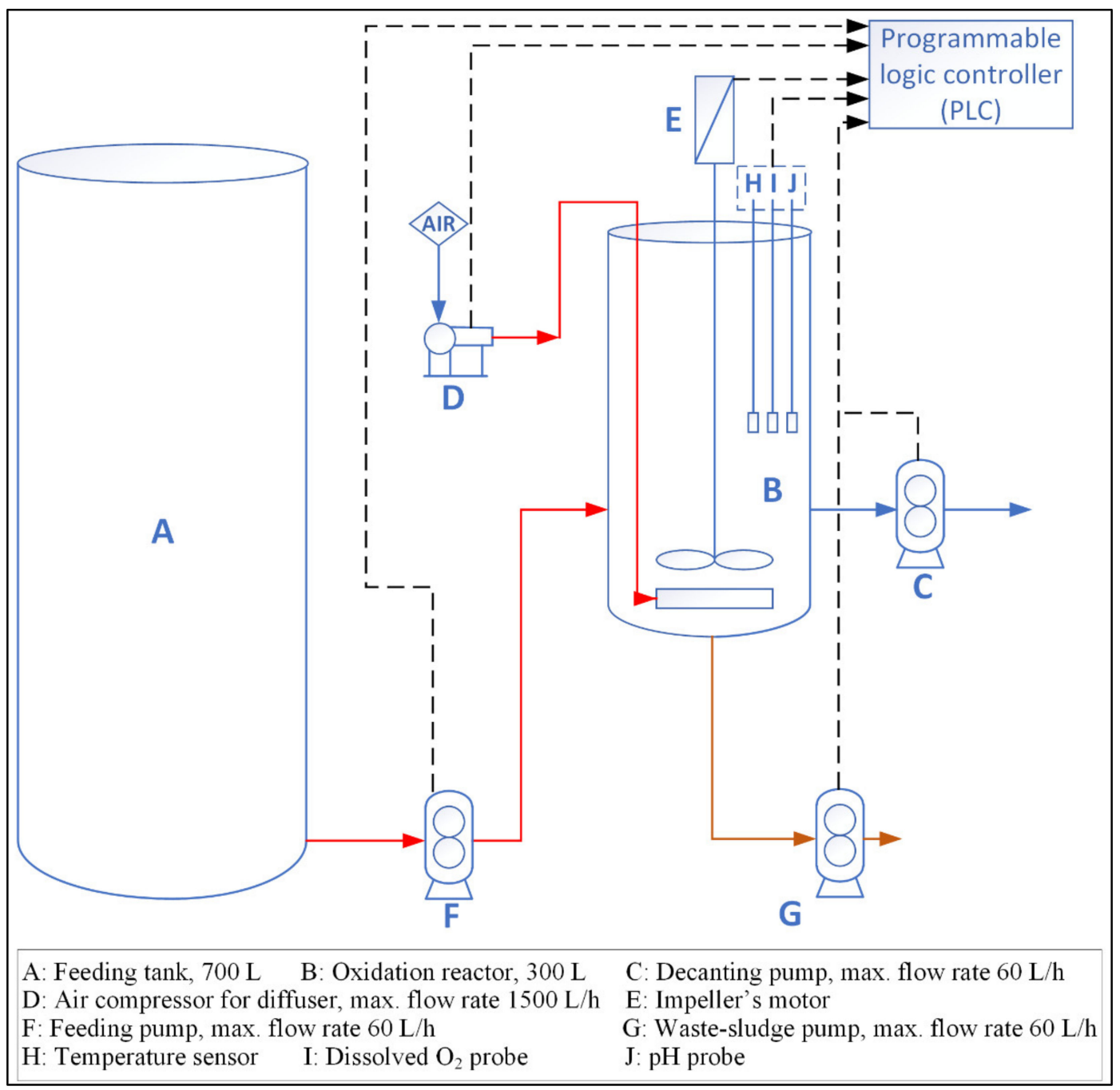

Figure 1. Schematic diagram of the pilot-scale sequencing batch reactor (SBR).

\subsection{Experimental Setup and Operation of the SBR System}

The NSTP wastewater influent samples were obtained on a daily basis from the inlet point to the aeration tank, where the influent is screened through coarse and fine screens to remove any large or fine particles. The samples were collected in $250 \mathrm{~L}$ containers and transferred within $30 \mathrm{~min}$ to the SBR reactor, ensuring that the development of the anaerobic condition was avoided prior to the SBR treatment process. No unusual foam or grease buildup was observed for the collected samples.

Two scenarios were applied to investigate the treatment efficiency of the SBR system. In the pre-anoxic denitrification, anoxic and oxic zones were employed sequentially. The pre-anoxic denitrification in the SBR was controlled by increasing the filling time and decreasing the settling time without any aeration (anoxic zone). In the post-anoxic denitrification, the cycle of oxic and-anoxic zones was established. In this cycle, the settling time was increased, and the filling time was decreased (without any aeration). Each cycle consisted of three runs, with different batch numbers and various combinations of filling time $\left(\mathrm{T}_{\mathrm{f}}\right)$, aeration time $\left(\mathrm{T}_{\mathrm{a}}\right)$, settling time $\left(\mathrm{T}_{\mathrm{s}}\right)$, and decanting time $\left(\mathrm{T}_{\mathrm{d}}\right)$. Table 2 shows the $T_{f}, T_{a}, T_{s}$, and $T_{d}$ values that were applied to each batch during pre-anoxic denitrification and post-anoxic denitrification processes. 
Table 2. Operational conditions of the pilot-scale SBR experiments.

\begin{tabular}{ccccccc}
\hline Scenarios & Batch No $^{*}$ & $\mathbf{T}_{\mathbf{f}}(\mathbf{h})$ & $\mathbf{T}_{\mathbf{a}} \mathbf{( h )}$ & $\mathbf{T}_{\mathbf{s}}(\mathbf{h})$ & $\mathbf{T}_{\mathbf{d}}(\mathbf{h})$ & $\mathbf{T}_{\text {total }}(\mathbf{h})$ \\
\hline & B1-1 & 8.0 & 4.0 & 2.8 & 0.25 & 15.1 \\
Pre-denitrification & B1-2 & 10.0 & 4.0 & 4.0 & 0.25 & 18.3 \\
(SCI) & B2-1 & 8.0 & 6.0 & 4.5 & 0.33 & 18.8 \\
& B2-2 & 12.0 & 6.0 & 8.0 & 0.25 & 26.3 \\
& B3-1 & 12.0 & 4.0 & 5.0 & 0.30 & 21.3 \\
& B3-2 & 10.0 & 4.0 & 4.0 & 0.30 & 18.3 \\
\hline Post-denitrification & B4-1 & 0.8 & 4.0 & 3.0 & 0.30 & 8.1 \\
(SCII) & B4-2 & 0.8 & 3.0 & 4.0 & 0.30 & 8.1 \\
& B5-1 & 1.0 & 4.0 & 8.0 & 0.25 & 13.3 \\
& B6-1 & 0.9 & 4.0 & 9.5 & 0.42 & 14.8 \\
& B6-2 & 0.5 & 4.0 & 11.0 & 0.25 & 15.8 \\
& B6-3 & 0.6 & 4.0 & 6.0 & 0.28 & 10.9 \\
\hline
\end{tabular}

* SCI: Scenario I, SCII, Scenario II, B1-B6: batch numbers, filling time $\left(\mathrm{T}_{\mathrm{f}}\right)$, aeration time $\left(\mathrm{T}_{\mathrm{a}}\right)$, and settling time $\left(\mathrm{T}_{\mathrm{s}}\right)$.

The operating volume of the oxidation reactor was kept at $240 \mathrm{~L}$. The startup was initiated by filling the oxidation reactor with the aerated wastewater collected from the aeration tank of NSTP. The preliminary cycle was obtained within $8 \mathrm{~h}$. The second preliminary batch was started by adding raw sewage from the aeration tank intake; as such, there was no need for adding sludge. The concentrations of mixed liquor suspended solids (MLSS) and mixed liquor volatile suspended solids (MLVSS) were kept at around 3500 and $1800 \mathrm{mg} \mathrm{L}^{-1}$, respectively. The average sludge retention time (SRT) was calculated to be 15 days, which is in good agreement with the reported values for the SBR process treatment of domestic wastewater [32,33]. The DO concentration during the aeration phase was measured by using an on-line DO probe and controlled simultaneously via an automated air compressor to maintain the DO concentration near $2 \mathrm{mg} \mathrm{L}^{-1}$. No external source of carbon was added to the SBR process since the average $\mathrm{C} / \mathrm{N}$ ratio of the influent was 9 . Gentle agitation was ensured by using an axial flow 3-blade impeller to retain the liquor in a well-mixed condition in filling and aeration phases. The pilot SBR system was operated in a temperature-controlled laboratory, which resulted in an average reactor temperature of $26.8 \pm 0.8^{\circ} \mathrm{C}$. All operations throughout the SBR experiments were controlled by a programmable logic controller (PLC) integrated into the system.

The removal efficiency (RE, \%) of each wastewater quality parameter was calculated by using Equation (1):

$$
R E(\%)=\frac{C_{\text {Inf }}-C_{E f f}}{C_{\text {Inf }}} \times 100,
$$

where $C_{\text {Inf }}$ is the concentration of the parameter in the influent, and $C_{E f f}$ is the concentration of the parameter in the effluent. Each analysis for the quantitative determination of wastewater quality parameters was performed in triplicate, and average results were reported. The statistical analyses of the dataset and the correlation statistics were obtained with the aid of SPSS (Statistical Package for the Social Sciences, IBM Corp., Armonk, NY, USA) Released 2016. IBM SPSS Statistics for Windows, Version 24.0. (IBM Corp, Armonk, NY, USA).

\section{Results and Discussion}

\subsection{Nitrogen Removal}

The variations of influent and effluent concentrations and removal efficiencies (RE) of $\mathrm{NH}_{3}-\mathrm{N}$, $\mathrm{NO}_{3}-\mathrm{N}$, and TN during the SBR pilot-scale batch experiments are shown in Figure 2. The average effluent concentrations of $\mathrm{NH}_{3}-\mathrm{N}$ after pre-anoxic denitrification scenario I (SCI) and oxic post nitrification scenario II (SCII) were found to be $2.59 \pm 0.48 \mathrm{mg} \mathrm{L}^{-1}$ and $0.98 \pm 0.86 \mathrm{mg} \mathrm{L}^{-1}$, respectively. The highest $\mathrm{NH}_{3}-\mathrm{N}$ removal efficiency of $99.9 \%$ was achieved by SCII (Batch\# 6-4), while SCI resulted 
in the lowest $\mathrm{NH}_{3}-\mathrm{N}$ removal efficiency of 77.0\% (Batch\# 3-1). These results reveal that more favorable conditions for the oxidation of $\mathrm{NH}_{3}-\mathrm{N}$ were provided by SCII, where the average $\mathrm{T}_{\mathrm{a}} / \mathrm{T}_{\text {total }}=0.36$, while the average $\mathrm{T}_{\mathrm{a}} / \mathrm{T}_{\text {total }}$ in SCI was 0.24 .

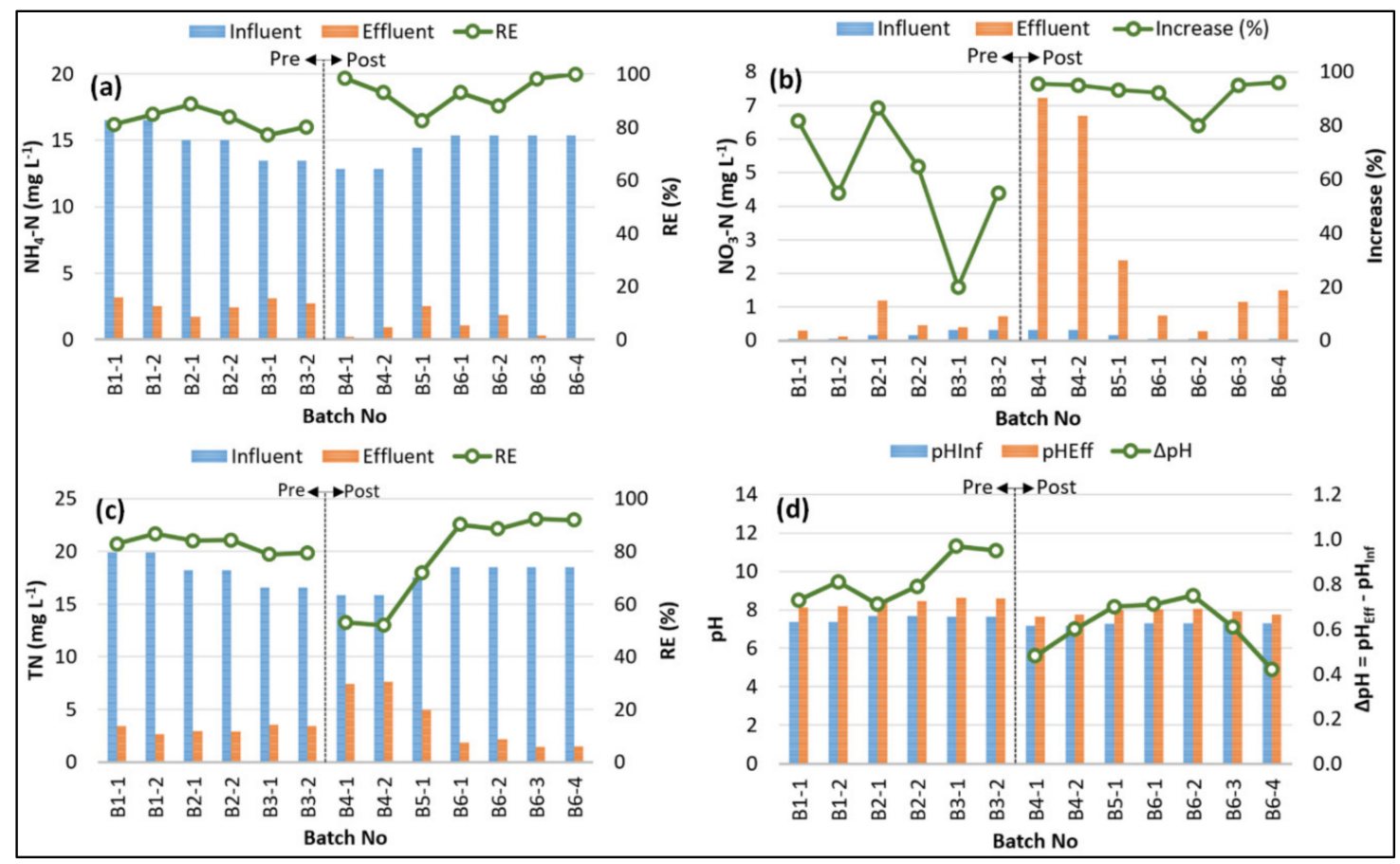

Figure 2. Variations of $(\mathbf{a})$ nitrogen $\left(\mathrm{NH}_{3}-\mathrm{N}\right),(\mathbf{b})$ nitrate-nitrogen $\left(\mathrm{NO}_{3}-\mathrm{N}\right)$, (c) total nitrogen $(\mathrm{TN})$, and (d) $\mathrm{pH}$.

The primary product of nitrification during the SBR experiments was $\mathrm{NO}_{3}-\mathrm{N}$, which accumulated up to $7.2 \mathrm{mg} \mathrm{L}^{-1}$, while the $\mathrm{NO}_{2}-\mathrm{N}$ concentration was always below the quantification limit. The average $\mathrm{NO}_{3}-\mathrm{N}$ accumulation ratios (\% increase) in SCI and SCII were calculated as $60.6 \%( \pm 21.9)$ and $92.5 \%$ $( \pm 5.19)$, respectively. The level of $\mathrm{NO}_{3}-\mathrm{N}$ accumulation could be ascribed to (1) the higher activity of ammonia-oxidizing bacteria (AOB) and more effective nitrification in SCII, and (2) the more efficient denitrification process and nitrite-oxidizing bacteria (NOB) activity in SCI, where the ratio of total anoxic period to total time $\left(\left(\mathrm{T}_{\mathrm{f}}+\mathrm{T}_{\mathrm{s}}\right) / \mathrm{T}_{\text {total }}\right)$ was higher than that of SCII. High $\mathrm{NO}_{3}-\mathrm{N}$ accumulation has been reported by several previously published SBR studies $[8,21,33,34]$.

The TN removal efficiency is dependent on the performances of nitrification and denitrification processes $[22,35,36]$. The average TN concentrations measured for effluent samples of SCI and SCII were $3.13 \pm 0.33 \mathrm{mg} \mathrm{L}^{-1}$ and $3.83 \pm 2.57 \mathrm{mg} \mathrm{L}^{-1}$, respectively. The average TN removal efficiencies of SCI and SCII were $82.7 \%( \pm 2.78)$ and $77.1 \%( \pm 16.9)$, respectively. The highest TN removal efficiency reached 92\% after the SBR cycles in Batch\# 6-3 and 6-4 were completed. It is evident from Figure $2 \mathrm{a}-\mathrm{c}$ that the nitrification performance played a predominant role compared to the denitrification process in reaching the highest TN removal in these two cases. These findings showed that post-anoxic denitrification (SCII) could perform better TN removal than pre-anoxic denitrification (SCI), corroborating earlier reported studies [21,37].

The $\mathrm{pH}$ of the SBR experiments conducted in this work was not controlled, and the effluent $\mathrm{pH}$ values ranged between 7.6 and 8.6, with an average of 8.1. The $\mathrm{pH}$ change $\left(\Delta_{\mathrm{pH}}=\mathrm{pH} \mathrm{Eff}_{\mathrm{pH}}-\mathrm{pH}_{\text {Inf }}\right)$ throughout the SBR experiments is indicated in Figure $2 d$. It can be concluded from Figure $2 d$ that $\mathrm{pH}_{\text {Eff }}$ was always greater than $\mathrm{pH}_{\text {Inf }}$, which could be attributed to the domination of the denitrification process in SBR experiments, inducing an increase in $\mathrm{pH}$. The average $\Delta_{\mathrm{pH}}$ values calculated for SCI and SCII were $0.83 \pm 0.10$ and $0.61 \pm 0.11$, respectively. High $\mathrm{NH}_{3}-\mathrm{N}$ removal efficiencies and high $\mathrm{NO}_{3}-\mathrm{N}$ accumulation rates observed in SCII were accompanied by low $\Delta_{\mathrm{pH}}$ values, implying that nitrification 
was the governing process and repressed the excessive $\mathrm{pH}$ increase due to the denitrification process since the allocated time for aeration was greater than that of anoxic periods in SCII $\left(T_{a}>T_{f}+T_{S}\right)$. On the other hand, SCI having a longer period of time assigned for anoxic conditions $\left(T_{f}+T_{S}>\right.$ $\mathrm{T}_{\mathrm{a}}$ ) yielded greater $\Delta_{\mathrm{pH}}$ because of the effective denitrification that increased the alkalinity of the solution $[30,38-40]$.

\section{2. $\mathrm{COD}, \mathrm{BOD}_{5}$, and $\mathrm{PO}_{4}{ }^{3-}$ Removal}

Figure 3 depicts the changes in influent and effluent concentrations and removal efficiencies (RE) of $\mathrm{COD}, \mathrm{BOD}_{5}$, and $\mathrm{PO}_{4}{ }^{3-}$ through the SBR plot scale batch experiments. The average effluent COD concentrations of SCI and SCII were computed to be $28.0 \pm 3.84$ and $27.7 \pm 16.2 \mathrm{mg} \mathrm{L}^{-1}$, respectively. Even though the average effluent COD concentrations of both scenarios were very close, the average COD removal efficiency of the SCII was greater than that of SCI due to the higher average influent COD concentration of SCII. The average COD removal efficiencies of SCI and SCII were 78.6\% $( \pm 5.0)$ and $90.7 \%( \pm 6.4)$, respectively. The SCII attained the highest COD removal efficiency of $99.1 \%$ at the end of Batch\# 6-4, which could be clarified by the faster filling phase, with the longer aeration and settling periods dedicated in SCII eventuating a better COD removal efficiency [20]. As a result, it implies that the post-anoxic denitrification scenario was more effective than the pre-anoxic denitrification scenario in terms of COD removal.

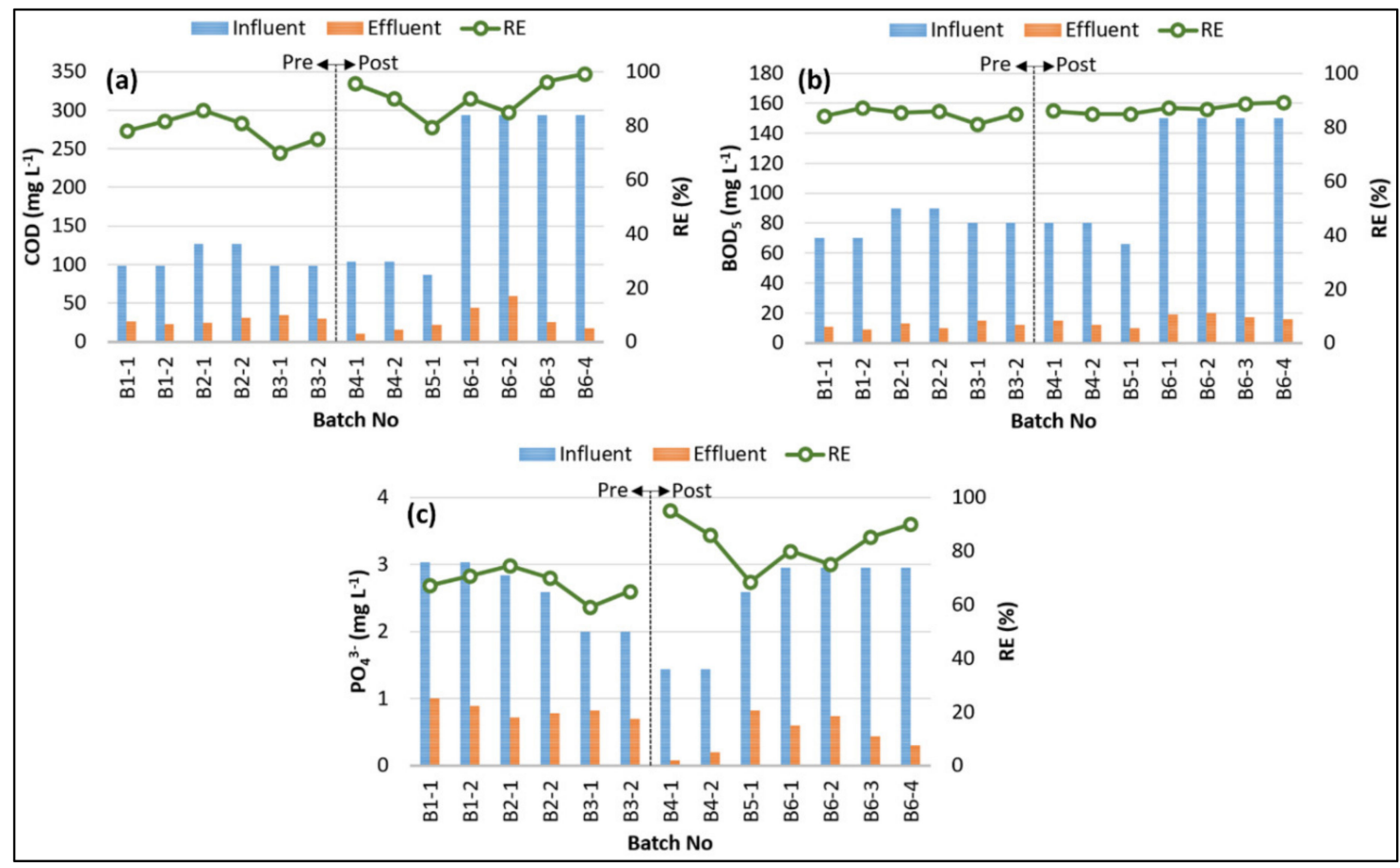

Figure 3. Variations and removal efficiencies of (a) the chemical oxygen demand (COD), (b) the 5-day biological oxygen demand $\left(\mathrm{BOD}_{5}\right)$, and (c) phosphate $\left(\mathrm{PO}_{4}{ }^{3-}\right)$.

$\mathrm{BOD}_{5}$ removal could be used as an indicator of the treatment efficiencies of the biological treatment processes $[41,42]$. The influent $\mathrm{BOD}_{5}$ concentrations indicated important decreases after the SBR experiments, with average removal efficiencies of $84.9 \%( \pm 1.84)$ and $86.8 \%( \pm 1.60)$ for SCI and SCII, respectively. As demonstrated in Figure $3 b$, the $\mathrm{BOD}_{5}$ removal efficiency did not fluctuate much and resulted in a low standard deviation value $( \pm 1.98)$ for all the experiments. The highest $\mathrm{BOD}_{5}$ removal efficiency of $88 \%$ was observed for Batch\# 6 , where the influent $\mathrm{BOD}_{5}$ concentration was the maximum among all the SBR experiments. The SCII provided higher removal efficiencies for both COD and $\mathrm{BOD}_{5}$ parameters, even for their higher influent concentrations, compared to the SCI, which might be ascribed to the more effective oxidation of organic matter allowed by batch experiments in SCI. 
The average influent $\mathrm{PO}_{4}{ }^{3-}$ concentration decreased from $2.52 \pm 0.57$ to $0.62 \pm 0.27 \mathrm{mg} \mathrm{L}^{-1}$, with an average removal efficiency of $75.9 \%( \pm 10.3)$, including both scenarios. The $\mathrm{PO}_{4}{ }^{3-}$ removal efficiency of both SCI and SCII indicates similar values in terms of COD and $\mathrm{NH}_{3}-\mathrm{N}$ removal efficiencies. The SCII provided a better $\mathrm{PO}_{4}{ }^{3-}$ removal rate $(82.8 \%)$ than that of SCI $(67.7 \%)$, which was also experienced for $\mathrm{NH}_{3}-\mathrm{N}, \mathrm{COD}$, and $\mathrm{BOD}_{5}$ removals. In the case of simultaneous nitrogen and phosphorus treatment, the competition between NOBs and phosphorus-accumulating organisms (PAOs) leads to unsteady $\mathrm{PO}_{4}{ }^{3-}$ removal, unless the COD amount of influent is sufficient $[37,43,44]$. In this work, the COD content of the influent was not a critical limiting factor for $\mathrm{PO}_{4}{ }^{3-}$ removal as it was most likely provided by the available carbon throughout the oxic period, particularly in SCII. In addition to this, Kundu, Debsarkar and Mukherjee [39] addressed that higher phosphorus uptakes could be achieved when SRT was less than 25 days, which could also support the efficient $\mathrm{PO}_{4}{ }^{3-}$ uptake results obtained here since the SRT of SBR experiments was 15 days.

\subsection{Turbidity, TSS, and TS Removal}

The variations of influent and effluent concentrations and removal efficiencies (RE) of Turbidity, TSS, and TS are indicated in Figure 4. The average influent values of turbidity, TSS, and TS were $77.5 \pm 7.36 \mathrm{NTU}, 926 \pm 83.3 \mathrm{mg} \mathrm{L}^{-1}$, and $3705 \pm 333 \mathrm{mg} \mathrm{L}^{-1}$, respectively. These values were reduced for the effluent to $2.88 \pm 0.99 \mathrm{NTU}, 17.4 \pm 5.14 \mathrm{mg} \mathrm{L}^{-1}$, and $104 \pm 34.4 \mathrm{mg} \mathrm{L}^{-1}$, with average removal efficiencies of $96.3 \%, 98.2 \%$, and $97.2 \%$, respectively. The removal rates of turbidity, TSS, and TS exhibited similar patterns, and the Pearson correlation coefficients $(p)$ between Turbidity RE $_{\text {and TSS }}$ RE, Turbidity $_{\mathrm{RE}}$ and $\mathrm{TS} \mathrm{RE}_{\mathrm{RE}}$, and TSS $\mathrm{RE}$ and TS $\mathrm{RE}$ were computed to be $0.96,0.99$, and 0.98 , respectively (within a 95\% confidence interval). These very strong correlations calculated for the removal efficiencies of turbidity, TSS, and TS parameters suggest that their removals were controlled by a common mechanism, which is the sedimentation phase of the SBR experiments. The SCII achieved slightly higher removal efficiencies for all these parameters in comparison with the SCI. This finding could be linked to the longer settling times given in the SCII compared to the SCI, providing the colloidal solids and the suspended solids with enough time to accumulate and settle [14,42].

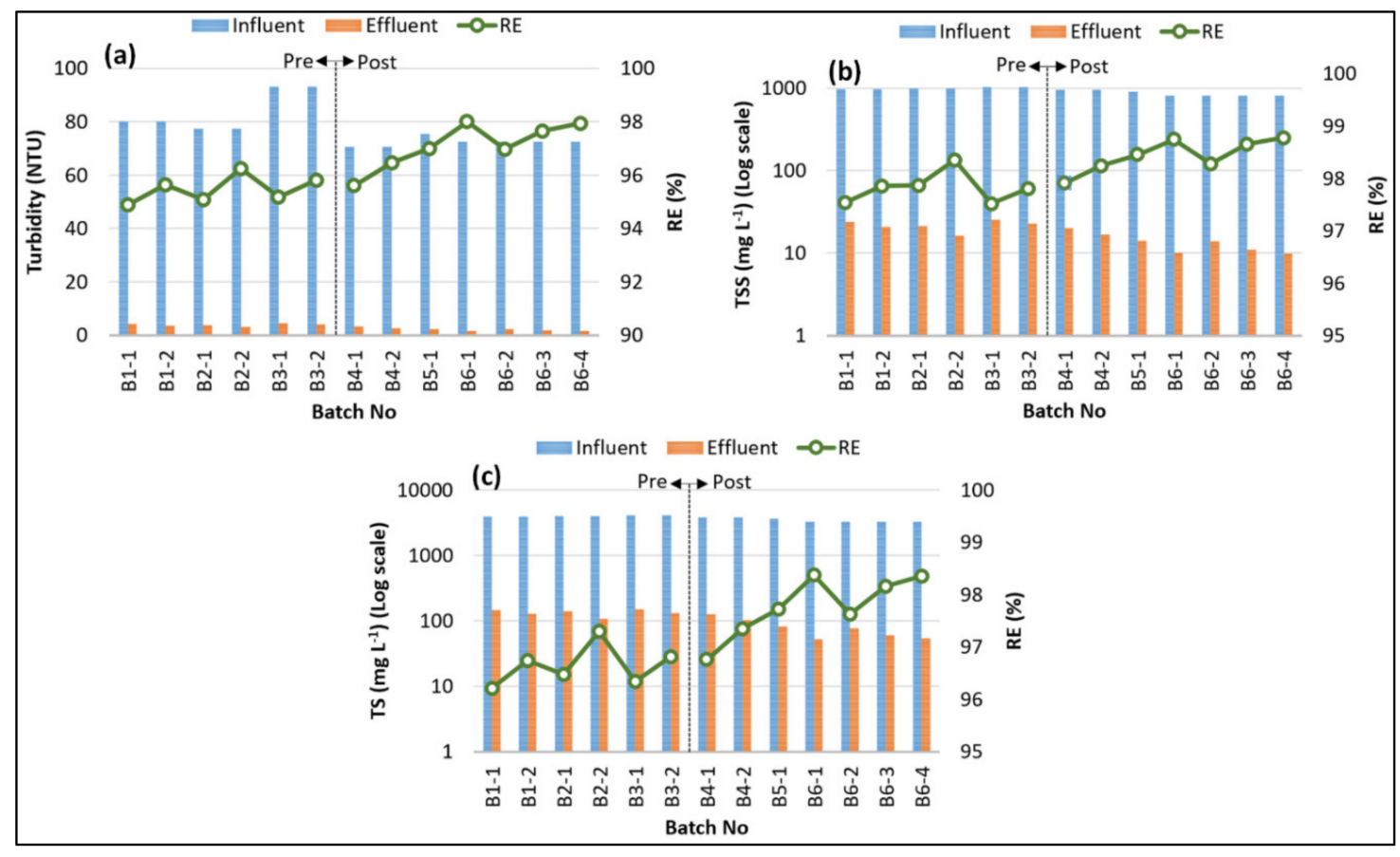

Figure 4. Variations and removal efficiencies of (a) turbidity, (b) total suspended solids (TSS), and (c) total solids (TS). 


\subsection{Effects of Parameters on the SBR System Performance}

The correlation statistics were applied to removal efficiencies of wastewater quality parameters, the $\mathrm{NO}_{3}-\mathrm{N}$ accumulation rate $\left(\mathrm{NO}_{3}-\mathrm{N}_{\mathrm{AR}}\right)$, and operational parameters of the SBR experiments in order to statistically explain the effects of operational parameters on the performance of the SBR system. The correlation matrix, including $p$ values between each parameter, is shown in Table 3. As observed in Section 3.3., Turb.RE, $\mathrm{TSS}_{\mathrm{RE}}$, and $\mathrm{TS}_{\mathrm{RE}}$ were strongly correlated with each other, and they indicated very strong correlations with the ratio of the settling period to the total batch runtime $\left(T_{\mathrm{s}} / \mathrm{T}_{\text {total }}\right)$. Increasing $\mathrm{T}_{\mathrm{S}} / \mathrm{T}_{\text {total }}$ provides more time for particles to be settled down efficiently, which importantly increases Turb.RE, $\mathrm{TSS}_{\mathrm{RE}}$, and $\mathrm{TS}_{\mathrm{RE}}$.

Table 3. Correlation matrix for the removal efficiencies of wastewater quality parameters and operational parameters of the SBR experiments.

\begin{tabular}{cccccccccc}
\hline${ }^{*}$ Parameters & $\mathbf{N H}_{\mathbf{3}}-\mathbf{N}_{\mathbf{R E}}$ & $\mathbf{N O}_{\mathbf{3}}-\mathbf{N}_{\mathbf{A R}}$ & $\mathbf{T N}_{\mathbf{R E}}$ & $\mathbf{C O D}_{\mathbf{R E}}$ & $\mathbf{B O D}_{\mathbf{R E}}$ & $\mathbf{P O}_{\mathbf{4}}{ }^{3-} \mathbf{R E}$ & Turb.RE & $\mathbf{T S S}_{\mathbf{R E}}$ & $\mathbf{T S}_{\mathbf{R E}}$ \\
\hline $\mathrm{T}_{\mathrm{f}} / \mathrm{T}_{\text {total }}$ & -0.76 & -0.77 & - & -0.76 & -0.56 & -0.75 & - & - & - \\
$\mathrm{T}_{\mathrm{a}} / \mathrm{T}_{\text {total }}$ & $\mathbf{0 . 8 6}$ & 0.74 & 0.61 & $\mathbf{0 . 8 6}$ & 0.51 & 0.91 & - & - & - \\
$\mathrm{T}_{\mathrm{s}} / \mathrm{T}_{\text {total }}$ & - & 0.58 & 0.51 & 0.50 & - & - & $\mathbf{0 . 8 4}$ & $\mathbf{0 . 8 0}$ & $\mathbf{0 . 8 3}$ \\
$\left(\mathrm{T}_{\mathrm{f}}+\mathrm{T}_{\mathrm{s}}\right) / \mathrm{T}_{\text {total }}$ & $\mathbf{- 0 . 8 7}$ & -0.74 & - & $\mathbf{- 0 . 8 6}$ & -0.51 & $\mathbf{- 0 . 9 2}$ & - & - & - \\
\hline
\end{tabular}

Only $p \geq 0.5$ and $p \leq-0.5$ are shown. Negative correlations are shown in italic. Very strong correlations, $p \geq 0.8$ and $p \leq-0.8$, are shown in bold, filling time $\left(\mathrm{T}_{\mathrm{f}}\right)$, aeration time $\left(\mathrm{T}_{\mathrm{a}}\right)$, and settling time $\left(\mathrm{T}_{\mathrm{s}}\right)$.

The ratio of the oxic period to total batch runtime $\left(T_{a} / T_{\text {total }}\right)$ was assessed in relation to its impact on the performance parameters of the SBR system. The $T_{a} / T_{\text {total }}$ ratio presented moderate-to-very strong positive correlations with $\mathrm{BOD}_{5 \mathrm{RE}}(0.51), \mathrm{TN}_{\mathrm{RE}}(0.61), \mathrm{NO}_{3}-\mathrm{N}_{\mathrm{AR}}(0.74), \mathrm{NH}_{3}-\mathrm{N}_{\mathrm{RE}}(0.86), \mathrm{COD}_{\mathrm{RE}}$ (0.86), and $\mathrm{PO}_{4}{ }^{3-} \mathrm{RE}(0.91)$, which reveals that the oxidation of both carbonaceous substrates and $\mathrm{NH}_{3}-\mathrm{N}$, accumulation of phosphates by PAOs, and accumulation of $\mathrm{NO}_{3}-\mathrm{N}$ due to nitrification were significantly enhanced when more oxic zones were provided by increasing $T_{a} / T_{\text {total }}$.

The ratios of anoxic periods $\left(T_{f}, T_{s}\right.$, and $\left.T_{f}+T_{s}\right)$ to total batch runtime $\left(T_{\text {total }}\right)$ were evaluated regarding their effects on the SBR performance. Both $T_{f} / T_{\text {total }}$ and $\left(T_{f}+T_{s}\right) / T_{\text {total }}$ ratios indicated moderate-to-very strong and negative correlations with $\mathrm{BOD}_{5 \mathrm{RE}}, \mathrm{PO}_{4}{ }^{3-}{ }_{\mathrm{RE}}, \mathrm{COD}_{\mathrm{RE}}, \mathrm{NH}_{3}-\mathrm{N}_{\mathrm{RE}}$, and $\mathrm{NO}_{3}-\mathrm{N}_{\mathrm{AR}}$, revealing that increasing the $\mathrm{T}_{\mathrm{f}}$ and $\mathrm{T}_{\mathrm{f}}+\mathrm{T}_{\mathrm{s}}$ periods weakened the removal efficiencies of $\mathrm{BOD}_{5}, \mathrm{PO}_{4}{ }^{3-}, \mathrm{COD}$, and $\mathrm{NH}_{3}-\mathrm{N}$, while the effluent $\mathrm{NO}_{3}-\mathrm{N}$ concentration was reduced by increasing the anoxic periods. On the other hand, the $\mathrm{T}_{\mathrm{s}} / \mathrm{T}_{\text {total }}$ ratio exhibited moderate and positive correlations with $\mathrm{COD}_{\mathrm{RE}}(0.50), \mathrm{TN}_{\mathrm{RE}}(0.51)$, and $\mathrm{NO}_{3}-\mathrm{N}_{\mathrm{AR}}$ (0.58). As a general trend, the $\mathrm{COD}$ and $\mathrm{NO}_{3}-\mathrm{N}$ removal efficiencies increase, with an increase in $T_{S}$ representing the period of the anoxic zone $[24,45,46]$. During this anoxic period, the denitrification process is achieved by using the COD as a carbon source and electron donor, and this process is responsible for $\mathrm{COD}$ and $\mathrm{NO}_{3}-\mathrm{N}$ removal. In addition, the particulate non-biodegradable fraction of COD can settle down during the sedimentation phase, which can also increase the COD removal rate as $T_{s}$ increases. The reason why a positive correlation between $\mathrm{T}_{\mathrm{f}} / \mathrm{T}_{\text {total }}$ and COD removal was not obtained could be attributed to the very low influent $\mathrm{NO}_{2}-\mathrm{N}$ and $\mathrm{NO}_{3}-\mathrm{N}$ concentrations, where the effect of the denitrification process on COD consumption is not statistically sound.

\subsection{Comparison of the SBR System Performance with the Literature}

The removal efficiencies of COD, $\mathrm{TN}$, and $\mathrm{PO}_{4}{ }^{3-}$ achieved by the pilot-scale SBR system with the post-anoxic denitrification scenario in this study were compared to similar reported works in the literature for simultaneous COD and nutrient removal using lab/bench-scale SBR systems. As demonstrated in Table 4, the $\mathrm{COD}, \mathrm{TN}$, and $\mathrm{PO}_{4}{ }^{3-}$ removal efficiencies attained in this research are in good agreement with the literature data. Noticeably, the studies that investigated SBR systems for treating synthetic wastewater influent performed better in terms of the $\mathrm{COD}, \mathrm{TN}$, and $\mathrm{PO}_{4}{ }^{3-}$ removal efficiencies. However, the pilot-scale SBR system with post-anoxic denitrification demonstrated an 
excellent performance in the removal of COD (91\%), nitrogen (83\%), and phosphate (90\%), in comparison with the others reported for domestic wastewater influent.

Table 4. Comparison of COD, TN, and phosphorus removal efficiencies with the literature.

\begin{tabular}{cccccc}
\hline \multirow{2}{*}{ Wastewater Type } & \multirow{2}{*}{$\begin{array}{c}\text { Reactor } \\
\text { Volume (L) }\end{array}$} & \multicolumn{2}{c}{ Removal Efficiency (\%) } & \multirow{2}{*}{ Reference } \\
\cline { 3 - 5 } & & COD & TN & Phosphate & \\
\hline Domestic wastewater & 3.5 & 87 & 83 & 74 & {$[36]$} \\
Domestic wastewater & 5 & 90 & 78 & 56 & {$[32]$} \\
Domestic wastewater & 10 & 85 & 86 & 82 & {$[41]$} \\
Synthetic wastewater & 10 & 97 & 98 & 80 & {$[47]$} \\
Synthetic sanitary sewer & 14 & 94 & 96 & 90 & {$[34]$} \\
Domestic wastewater & 25 & 95 & 78 & 87 & {$[39]$} \\
Domestic wastewater & 240 & 91 & 83 & 83 & This work \\
\hline
\end{tabular}

The average effluent concentrations of the wastewater quality parameters calculated for NSTP and the obtained pilot-scale SBR system with post-anoxic denitrification in this study were compared with the maximum allowable discharge levels for the treated sewage wastewater imposed by the KSA Ministry of Environment, Water, and Agriculture regulations [48]. It is evident from Table 5 that the effluent concentrations of both NSTP and the proposed SBR system complied with the local standards. The removal efficiencies of turbidity, TSS, TS, and $\mathrm{NH}_{3}-\mathrm{N}$ computed for NSTP and the proposed SBR systems were comparable. However, the proposed SBR system presented herein improved the treatment efficiencies of $\mathrm{BOD}_{5}, \mathrm{COD}, \mathrm{TN}$, and $\mathrm{PO}_{4}{ }^{3-}$ by $6 \%, 16 \%, 17 \%$, and $41 \%$, respectively, in comparison with NSTP. Therefore, the SBR system with a post-anoxic denitrification configuration can be considered as an efficient method for domestic wastewater treatment in terms of the treatment performance, operational simplicity, flexibility in the operational parameters, and cost-effectiveness, by providing anoxic and oxic conditions in the same tank.

Table 5. Comparison of NSTP and SBR effluents and their performances.

\begin{tabular}{|c|c|c|c|c|c|c|}
\hline \multirow{2}{*}{ * Parameter } & \multicolumn{3}{|c|}{ Effluent } & \multirow{2}{*}{$\begin{array}{l}\text { Discharge Limit } \\
\text { (KSA) }\end{array}$} & \multicolumn{2}{|c|}{ Removal Efficiency (\%) } \\
\hline & Unit & NSTP & SBR & & NSTP & SBR \\
\hline $\mathrm{pH}$ & $\mathrm{pH}$ unit & $7.61 \pm 0.25$ & $7.87 \pm 0.15$ & {$[6.0-8.4]$} & - & - \\
\hline Turbidity & NTU & $2.63 \pm 1.31$ & $2.10 \pm 0.55$ & 5 & 97 & 97 \\
\hline TSS & $\mathrm{mg} \mathrm{L}^{-1}$ & $25.2 \pm 8.44$ & $13.7 \pm 3.51$ & 40 & 97 & 98 \\
\hline TS & $\mathrm{mg} \mathrm{L}^{-1}$ & $98.8 \pm 10.0$ & $78.8 \pm 24.9$ & - & 97 & 98 \\
\hline $\mathrm{NO}_{3}-\mathrm{N}$ & $\mathrm{mg} \mathrm{L}^{-1}$ & $3.29 \pm 1.20$ & $2.85 \pm 2.67$ & 10 & - & - \\
\hline $\mathrm{NH}_{3}-\mathrm{N}$ & $\mathrm{mg} \mathrm{L}^{-1}$ & $1.78 \pm 2.27$ & $0.98 \pm 0.86$ & 5 & 91 & 93 \\
\hline $\mathrm{TN}$ & $\mathrm{mg} \mathrm{L}^{-1}$ & $5.90 \pm 1.06$ & $3.13 \pm 0.33$ & - & 66 & 83 \\
\hline $\mathrm{PO}_{4}{ }^{3-}$ & $\mathrm{mg} \mathrm{L}^{-1}$ & $1.29 \pm 1.13$ & $0.45 \pm 0.26$ & 10 & 42 & 83 \\
\hline COD & $\mathrm{mg} \mathrm{L}^{-1}$ & $44.8 \pm 21.6$ & $27.7 \pm 16.2$ & 50 & 75 & 91 \\
\hline $\mathrm{BOD}_{5}$ & $\mathrm{mg} \mathrm{L}^{-1}$ & $15.0 \pm 9.02$ & $11.7 \pm 1.97$ & 40 & 81 & 87 \\
\hline
\end{tabular}

* Total suspended solids (TSS), total solids (TS), nitrite-nitrogen $\left(\mathrm{NO}_{2}{ }^{-} \mathrm{N}\right)$, nitrate-nitrogen $\left(\mathrm{NO}_{3}{ }^{-} \mathrm{N}\right)$, ammonia-nitrogen $\left(\mathrm{NH}_{3}-\mathrm{N}\right)$, total nitrogen $(\mathrm{TN})$, phosphate $\left(\mathrm{PO}_{4}{ }^{3-}\right)$, chemical oxygen demand (COD), and 5-day biological oxygen demand $\left(\mathrm{BOD}_{5}\right)$, NSTP: North Sewage Treatment Plant, SBR: Seuential bach reactor.

\section{Conclusions}

In this work, the establishment and testing of a pilot-scale SBR system were successfully practiced in order to investigate the system performance for the treatment of municipal wastewater samples obtained from the North Sewage Treatment Plant (NSTP) in the Dhahran area of the Eastern Province, KSA. Two scenarios were performed, consisting of pre-anoxic denitrification and post-anoxic denitrification, to study the treatment of wastewater quality parameters. During four months of system operation, 
satisfactory and stable removal efficiencies of the targeted parameters were achieved. The correlation statistics results revealed that treatment efficiencies of $\mathrm{NH}_{3}-\mathrm{N}, \mathrm{TN}, \mathrm{PO}_{4}{ }^{3-}, \mathrm{COD}$, and $\mathrm{BOD}_{5}$ were significantly improved by increasing the aeration time fraction in the total SBR runtime, while increasing the total anoxic period in the total SBR runtime improved the $\mathrm{NO}_{3}-\mathrm{N}$ removal efficiency. The treatment efficiencies of turbidity, TSS, and TS indicated very strong and positive correlations with the ratio of the settling period to total batch runtime. The post-anoxic denitrification scenario resulted in the maximum treatment efficiencies of $\mathrm{NH}_{3}-\mathrm{N}(99.9 \%), \mathrm{TN}(92.0 \%), \mathrm{PO}_{4}{ }^{3-}(90.0 \%), \mathrm{COD}(99.1 \%), \mathrm{BOD}_{5}$ $(89.3 \%)$, turbidity $(97.9 \%)$, TSS $(98.8 \%)$, and TS $(98.4 \%)$ when the filling, aeration, sedimentation, and decanting times were set to $0.58,6.0,6.0$, and $0.20 \mathrm{~h}$, respectively. The effluent concentrations of the targeted wastewater quality parameters computed for the proposed SBR system were below the local standards, and the performance of the proposed SBR system was better than that of NSTP in terms of the $\mathrm{BOD}_{5}, \mathrm{COD}, \mathrm{TN}$, and $\mathrm{PO}_{4}{ }^{3-}$ treatment efficiencies. Hence, the tested and proposed SBR process is a simple, efficient, flexible, cost-effective, and successful technology for the treatment of municipal wastewaters. The SBR process can be employed in remote areas in arid regions of KSA for wastewater treatment and reuse for sustainable water management.

Author Contributions: O.A. and A.A.B. conceived and designed the research idea. A.A. performed the experiments. I.A. and N.D.M. analyzed and interpreted the data. All authors wrote the manuscript and reviewed it. Project administration and funding acquisition were performed by O.A. All authors have read and agreed on the published version of the paper. All authors have read and agreed to the published version of the manuscript.

Funding: The authors acknowledge the financial support provided by King Abdulaziz City for Science and Technology (KACST), Saudi Arabia, for funding this work through grant number (10-WAT1336-46) and the support of the Deanship of Scientific Research (DSR) at Imam Abdulrahman bin Faisal University (IAU).

Conflicts of Interest: The authors declare no conflict of interest.

\section{References}

1. Mu'azu, N.D.; Jarrah, N.; Zubair, M.; Alagha, O.; Health, P. Removal of phenolic compounds from water using sewage sludge-based activated carbon adsorption: A review. Int. J. Environ. Res. Public Health 2017, 14, 1094. [CrossRef] [PubMed]

2. Blackburne, R.; Yuan, Z.; Keller, J. Demonstration of nitrogen removal via nitrite in a sequencing batch reactor treating domestic wastewater. Water Res. 2008, 42, 2166-2176. [CrossRef] [PubMed]

3. Boon, A.G. Sequencing Batch Reactors: A Review. Water Environ. J. 2003, 17, 68-73. [CrossRef]

4. Boaventura, K. State observers for a biological wastewater nitrogen removal process in a sequential batch reactor. Bioresour. Technol. 2001, 79. [CrossRef]

5. Lochmatter, S.; Maillard, J.; Holliger, C. Nitrogen removal over nitrite by aeration control in aerobic granular sludge sequencing batch reactors. Int. J. Environ. Res. Public Health 2014, 11, 6955-6978. [CrossRef]

6. Li, J.; Liu, J.; Wang, D.; Chen, T.; Ma, T.; Wang, Z.; Zhuo, W. Accelerating Aerobic Sludge Granulation by Adding Dry Sewage Sludge Micropowder in Sequencing Batch Reactors. Int. J. Environ. Res. Public Health 2015, 12, 10056-10065. [CrossRef] [PubMed]

7. Aziz, H.A.; Puat, N.N.A.; Alazaiza, M.Y.D.; Hung, Y.T. Poultry Slaughterhouse Wastewater Treatment Using Submerged Fibers in an Attached Growth Sequential Batch Reactor. Int. J. Environ. Res. Public Health 2018, 15, 1734. [CrossRef]

8. Dutta, A.; Sarkar, S. Sequencing Batch Reactor for Wastewater Treatment: Recent Advances. Curr. Pol. Rep. 2015, 1, 177-190. [CrossRef]

9. Chang, H.N.; Moon, R.K.; Park, B.G.; Lim, S.-J.; Choi, D.W.; Lee, W.G.; Song, S.L.; Ahn, Y.H. Simulation of sequential batch reactor (SBR) operation for simultaneous removal of nitrogen and phosphorus. Bioprocess Eng. 2000, 23, 513-521. [CrossRef]

10. Guerrero, L.; Montalvo, S.; Huiliñir, C.; Barahona, A.; Borja, R.; Cortés, A. Simultaneous nitrificationdenitrification of wastewater: Effect of zeolite as a support in sequential batch reactor with step-feed strategy. Int. J. Environ. Sci. Technol. 2016, 13, 2325-2338. [CrossRef] 
11. Khursheed, A.; Gaur, R.Z.; Sharma, M.K.; Tyagi, V.K.; Khan, A.A.; Kazmi, A.A. Dependence of enhanced biological nitrogen removal on carbon to nitrogen and $\mathrm{rbCOD}$ to sbCOD ratios during sewage treatment in sequencing batch reactor. J. Clean Prod. 2018, 171, 1244-1254. [CrossRef]

12. Mees, J.B.; Gomes, S.D.; Hasan, S.D.; Gomes, B.M.; Boas, M.A. Nitrogen removal in a SBR operated with and without pre-denitrification: Effect of the carbon:nitrogen ratio and the cycle time. Environ. Technol. 2014, 35, 115-123. [CrossRef] [PubMed]

13. Mees, J.B.R.; Gomes, S.D.; Vilas Boas, M.A.; Gomes, B.M.; Passig, F.H. Kinetic behavior of nitrification in the post-treatment of poultry wastewater in a sequential batch reactor. Eng. Agric. 2011, 31, 954-964. [CrossRef]

14. Mace, S.; Mata-Alvarez, J. Utilization of SBR Technology for Wastewater Treatment: An Overview. Ind. Eng. Chem. Res. 2002, 41, 5539-5553. [CrossRef]

15. Nancharaiah, Y.V.; Sarvajith, M. Aerobic granular sludge process: A fast growing biological treatment for sustainable wastewater treatment. Curr. Opin. Environ. Sci. Health 2019, 12, 57-65. [CrossRef]

16. Surampalli, R. Nitrification, denitrification and phosphorus removal in sequential batch reactors. Bioresour. Technol. 1997, 61, 151-157. [CrossRef]

17. Thakur, C.; Srivastava, V.C.; Mall, I.D. Aerobic degradation of petroleum refinery wastewater in sequential batch reactor. J. Environ. Sci. Health A 2014, 49, 1436-1444. [CrossRef]

18. Wang, L.; Xu, J.-M.; Ma, S.-S.; Zhao, B.; Zhang, Z.-H.; Zhou, X.-M.; Zhang, H.-W. Biological nitrogen removal in a modified anoxic/oxic process for piggery wastewater treatment. Desalin. Water Treat. 2015, 57, 11266-11274. [CrossRef]

19. Yan, D.; He, J.; Zuo, X.; Li, Z. Simultaneous effect of organic carbon and ammonium on two-step nitrification within sequential batch reactor (SBR). Int. J. Environ. Sci. Technol. 2018, 16, 2239-2248. [CrossRef]

20. Chan, Y.J.; Chong, M.F.; Law, C.L.; Hassell, D.G. A review on anaerobic-aerobic treatment of industrial and municipal wastewater. Chem. Eng. J. 2009, 155. [CrossRef]

21. Winkler, M.; Coats, E.R.; Brinkman, C.K. Advancing post-anoxic denitrification for biological nutrient removal. Water Res. 2011, 45, 6119-6130. [CrossRef] [PubMed]

22. Pelaz, L.; Gomez, A.; Letona, A.; Garralon, G.; Fdz-Polanco, M. Sequencing batch reactor process for the removal of nitrogen from anaerobically treated domestic wastewater. Water Sci. Technol. 2018, 77, 1581-1590. [CrossRef] [PubMed]

23. Han, Y.; Qiu, S.; Zeng, H.; Ma, F.; Wang, J.; Qiu, Y.; An, X. Short-Term Effects of Tourmaline on Nitrogen Removals and Microbial Communities in a Sequencing Batch Reactor at Low Temperatures. Int. J. Environ. Res. Public Health 2018, 15, 2819. [CrossRef] [PubMed]

24. Sharma, B.; Ahlert, R.C. Nitrification and nitrogen removal. Water Res. 1977, 11, 897-925. [CrossRef]

25. Hanaki, K.; Hong, Z.; Matsuo, T. Production of Nitrous Oxide Gas during Denitrification of Wastewater. Water Sci. Technol. 1992, 26, 1027-1036. [CrossRef]

26. Sun, S.-P.; Nàcher, C.P.I.; Merkey, B.; Zhou, Q.; Xia, S.-Q.; Yang, D.-H.; Sun, J.-H.; Smets, B.F. Effective Biological Nitrogen Removal Treatment Processes for Domestic Wastewaters with Low C/N Ratios: A Review. Environ. Eng. Sci. 2010, 27, 111-126. [CrossRef]

27. Beccari, M.; Passino, R.; Ramadori, R.; Tandoi, V. Kinetics of dissimilatory nitrate and nitrite reduction in suspended growth cultures. Water Pollut. Control Fed. 1983, 55, 58-64.

28. Fontenot, Q.; Bonvillain, C.; Kilgen, M.; Boopathy, R. Effects of temperature, salinity, and carbon: Nitrogen ratio on sequencing batch reactor treating shrimp aquaculture wastewater. Bioresour. Technol. 2007, 98, 1700-1703. [CrossRef]

29. Jin, Y.X.; Li, X.L. Nitrogen and Phosphorus Removal in Synthetic Domestic Wastewater using SBBR Technology. Appl. Mech. Mater. 2012, 209, 1906-1909. [CrossRef]

30. Guo, Y.; Peng, Y.; Wang, B.; Li, B.; Zhao, M. Achieving simultaneous nitrogen removal of low $\mathrm{C} / \mathrm{N}$ wastewater and external sludge reutilization in a sequencing batch reactor. Chem. Eng. J. 2016, 306, 925-932. [CrossRef]

31. Rice, E.W.; Baird, R.B.; Eaton, A.D. Standard Methods for the Examination of Water and Wastewater, 23th ed.; American Water Works Association (AWWA, WEF and APHA): Washington, DC, USA, 2017; p. 1796.

32. Han, Y.; Sun, Y.; Chen, H.; Guo, X.; Yu, C.; Li, Y.; Liu, J.; Xiao, B. Effects of wastewater treatment processes on the sludge reduction system with 2,4-dichlorophenol: Sequencing batch reactor and anaerobic-anoxic-oxic process. J. Biotechnol. 2017, 251, 99-105. [CrossRef] [PubMed] 
33. Zhang, Y.; Wang, X.C.; Cheng, Z.; Li, Y.; Tang, J. Effects of additional fermented food wastes on nitrogen removal enhancement and sludge characteristics in a sequential batch reactor for wastewater treatment. Environ. Sci. Pollut. Res. Int. 2016, 23, 12890-12899. [CrossRef] [PubMed]

34. Callado, N.H.; Foresti, E. Removal of organic carbon, nitrogen and phosphorus in sequential batch reactors integrating the aerobic/anaerobic processes. Water Sci. Technol. 2001, 44, 263-270. [CrossRef] [PubMed]

35. Sun, F.; Lu, Y.; Wu, J. Comparison of operational strategies for nitrogen removal in aerobic granule sludge sequential batch reactor (AGS-SBR): A model-based evaluation. J. Environ. Chem. Eng. 2019, 7. [CrossRef]

36. Jakubaszek, A.; Stadnik, A. Efficiency of Sewage Treatment Plants in the Sequential Batch Reactor. Civil Environ. Eng. Rep. 2018, 28, 121-131. [CrossRef]

37. Chen, H.B.; Wang, D.B.; Li, X.M.; Yang, Q.; Zeng, G.M. Enhancement of post-anoxic denitrification for biological nutrient removal: Effect of different carbon sources. Environ. Sci. Pollut. Res. Int. 2015, 22, 5887-5894. [CrossRef]

38. Cho, B.C.; Chang, C.N.; Liaw, S.L.; Huang, P.T. The feasible sequential control strategy of treating high strength organic nitrogen wastewater with sequencing batch biofilm reactor. Water Sci. Technol. 2001, 43, 115-122. [CrossRef]

39. Kundu, P.; Debsarkar, A.; Mukherjee, S. Anoxic-oxic treatment of abattoir wastewater for simultaneous removal of carbon, nitrogen and phosphorous in a sequential batch reactor (SBR). Mater. Today Proc. 2016, 3, 3296-3309. [CrossRef]

40. Lan, C.J.; Kumar, M.; Wang, C.C.; Lin, J.G. Development of simultaneous partial nitrification, anammox and denitrification (SNAD) process in a sequential batch reactor. Bioresour. Technol. 2011, 102, 5514-5519. [CrossRef]

41. Chattaraj, S.; Purohit, H.J.; Sharma, A.; Jadeja, N.B.; Madamwar, D. Treatment of Common Effluent Treatment Plant Wastewater in a Sequential Anoxic-Oxic Batch Reactor by Developed Bacterial Consortium VN11. Appl. Biochem. Biotechnol. 2016, 179, 514-529. [CrossRef]

42. Showkat, U.; Najar, I.A. Study on the efficiency of sequential batch reactor (SBR)-based sewage treatment plant. Appl. Water Sci. 2018, 9. [CrossRef]

43. Kim, D.; Kim, T.-S.; Ryu, H.-D.; Lee, S.-I. Treatment of low carbon-to-nitrogen wastewater using two-stage sequencing batch reactor with independent nitrification. Process. Biochem. 2008, 43, 406-413. [CrossRef]

44. Hamada, K.; Kuba, T.; Torrico, V.; Okazaki, M.; Kusuda, T. Comparison of nutrient removal efficiency between pre- and post-denitrification wastewater treatments. Water Sci. Technol. 2006, 53, 169-175. [CrossRef] [PubMed]

45. Jaramillo, F.; Orchard, M.; Munoz, C.; Zamorano, M.; Antileo, C. Advanced strategies to improve nitrification process in sequencing batch reactors-A review. J. Environ. Manag. 2018, 218, 154-164. [CrossRef] [PubMed]

46. Zhu, G.; Peng, Y.; Li, B.; Guo, J.; Yang, Q.; Wang, S. Biological removal of nitrogen from wastewater. Rev. Environ. Contam. Toxicol. 2008, 192, 159-195. [CrossRef] [PubMed]

47. Akin, B.S.; Ugurlu, A. The effect of an anoxic zone on biological phosphorus removal by a sequential batch reactor. Bioresour. Technol. 2004, 94. [CrossRef]

48. MEWA. Water Pollutuion Control Regulation; Ministry of Environment, Water and Agriculture (MEWA): Riyadh, Saudi Arabia, 2020.

(C) 2020 by the authors. Licensee MDPI, Basel, Switzerland. This article is an open access article distributed under the terms and conditions of the Creative Commons Attribution (CC BY) license (http://creativecommons.org/licenses/by/4.0/). 